\title{
Aboriginal skeletons in the closet
}

\author{
Time to send them home
}

Scattered around the medical and scientific institutions of the world are the human remains of thousands of Australian Aborigines. ${ }^{2}$ Of the estimated 2000 skeletons, skulls, and fragments of bones held by European museums, most are in Britain. ${ }^{3}$ Their descendants want these relics back. ${ }^{4}$ Those currently responsible for them should surely comply with these requests.

The whole sorry story of the export of Aboriginal human remains began in the early nineteenth century with the enthusiasm for phrenology, the "science" of diagnosing the state of the mental faculties from skull measurements. ${ }^{5}$ Phrenologists wanted representative skulls of the world's races, and, according to a contemporary newspaper report, the shipment of Aboriginal skulls became the colony's "new export industry."

Later in the century evolutionary theories turned attention to the relative advancement of different races. On the basis of an examination of their skulls Australian Aborigines were assigned a place on the bottom rung of humanity, a position they sometimes shared with the Hottentot. Physical anthropologists needed Aboriginal skulls to complete their series. What was actually going on over this period was the "cooking up [of] objective looking sanctions for the myths of racial identity and European superiority." The world's colonisers were using evolutionary theory to buttress their claims to racial superiority over the people they were colonising.

Because it was assumed that the more primitive races were doomed to extinction the demand for Aboriginal material increased further. Grave robbing, contract killing, and murder augmented the supply. ${ }^{\circ}$ By the early twentieth century the enthusiasm for collecting such items had waned as scientific interest shifted from physical to social anthropology (Paul Turnbull, personal communication). And widespread enthusiasm for "scientific" racial theories went into possibly terminal decline after the Nazis used them to justify their extermination of "degenerate races," among whom were numbered Jews, gypsies, and Slavs. ${ }^{8}$

Meanwhile, British museums have held on to their collections of human remains, although most are no longer on public display (presumably through lack of interest). For the past few years Australian Aborigines have been campaigning for their return, with only limited success. They regard their continued presence in museums as doubly repugnant. Not only were they removed from Australia without the consent of Aborigines (and sometimes in direct opposition to their stated wishes) but once there the remains were used to "prove" theories about the inferiority of the Australian Aborigines. These theories had repercussions until well into this century: discriminatory policies predicated on the Aborigines' racial inferiority included their forcible segregation from the white population, the denial of adult suffrage, and the removal of half caste children ("intellectually above the Aborigine") from their parents.

Some museums have responded to the requests. Oxford's Pitt-Rivers Museum said that "the decision to return skeletal material was an easy one because it was totally irrelevant to this museum and should not have been here in the first place. ... We have had things for 75 years and nobody has ever asked for them until now." ${ }^{3}$ According to Glasgow's Kelvingrove Museum, "The stuff has sat here for a century and we don't have the personnel to do research on it." Remains have been "largely untouched and undocumented."

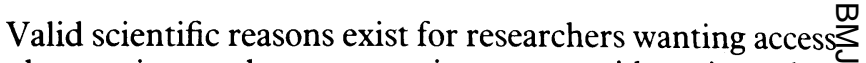
to the specimens: human remains can provide unique data on diet, patterns of disease, environmental adaptation, bios logical changes, and population affinities (with new tech? niques such as the polymerase chain reaction holding ou를 great potential).

But access does not mean perpetual curatorship, just å return of the remains to Aboriginal custody does not meañ their loss to science. The experience of the curator of thछ South Australian Museum's collection has been that when Aborigines are offered a real say in what happens to the material destruction does not necessarily follow. ${ }^{10}$ Anothey

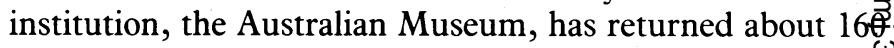
skeletal remains and continues to work on the identificatio and return or preservation of the others, depending on community wishes.

One tribe has allowed a physical anthropologist to examine 40 human remains in the Queensland Museum. "When hoु hands over the documentation, we'll decide how significant it is. In London they are not supplying us with the documenta tion. If they're doing significant research then they should prove it. Otherwise the items are just curios," said Bo Weatherall, an Aboriginal barrister leading the campaign foథ restitution. ' The point seems clear: if scientists have compelo ling reasons for researching human remains then they must learn how to communicate them to groups wider than theing peers. Anthropologists have a code of ethics that says that the rights and wishes of the people they study supersede their owif research needs. " Perhaps those few scientists who regarck scientific values as overriding the cultural beliefs of the peoplo they study should reconsider their own ethical positions.

This problem is not unique to Australian Aborigin $\$$ remains in British museums. Last year the United State $\overrightarrow{\bar{\sigma}}$ Congress passed a law giving museums deadlines by which they had to catalogue all human and cultural remains of the country's native peoples and consult with and be directed by their surviving communities over their fate. Going beyon this is a United Nations resolution requiring all signatories to return the remains of indigenous people held in museum collections.

What has this got to do with doctors today? According to one researcher, when it comes to questions of restitution the more "medical" an institution the more difficult it is to make any headway. Doctors could therefore do some leaning of their more blinkered colleagues. Our medical forebearso particularly anatomists and pathologists, were deeply impli cated in the whole gruesome business - from body snatchin to racial theorising that ended in genocide. Restitution of the human remains will hardly atone for their deeds, but it seems the least bad option at our disposal.

Deputy Editor, $B M \mathcal{F}$

TONY DELAMOTH零

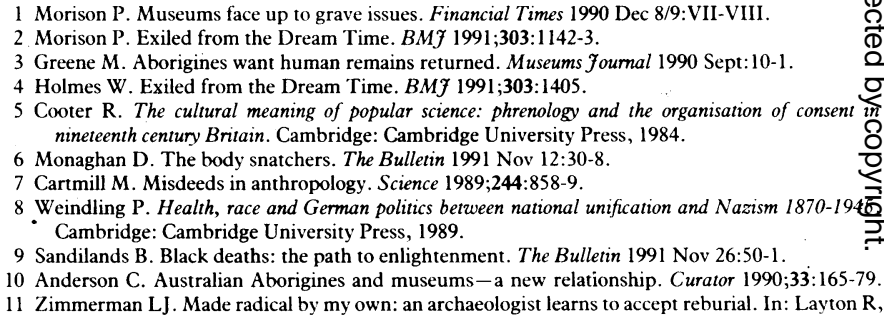

